\title{
Improving Students' Scientific Writing Ability through Blended learning-Based Collaborative Learning
}

\author{
https://doi.org/10.3991/ijet.v14i20.11457 \\ Dede Hasanuddin ( $\left.{ }^{\bowtie}\right)$, Emzir, Sabarti Akhadiah \\ State University of Jakarta, Jakarta, Indonesia \\ dedehasanudin pb07s3@mahasiswa.unj.ac.id
}

\begin{abstract}
Scientific writing is a way for someone to put the concept of thinking in written form so that other people can understand what is being thought. Students are the next generations who have idealism in thinking that needs to be nurtured. The purpose of this study was to improve the scientific writing of students through Collaborative Learning by utilizing blended learning technology. The research method used is action research, using collaborative learning that is applied in learning to write scientific paper. The students are expected to have logical thinking aspects, data objectivity, vocabulary mastery, use of Enhanced Spelling (EYD), use of effective sentences, and paragraph development. It can be concluded that collaborative learning can improve the ability to write scientific articles because in collaborative learning students are very active, motivated and always intrigued by their hearts and minds to solve problems faced in the same group and they can compete competitively, and motivate other students to achieve the maximum learning outcomes.
\end{abstract}

Keywords - Ability, Writing Scientific Paper, Students, Collaborative Learning.

\section{Introduction}

Writing represents a self-expression, what is in the mind is stated in writing The ability to write is an absolute (Zillmer \& Kuhn, 2018)thing that must be mastered by students in all study programs at a University. As a general course, it is very reasonable if Indonesian language courses must be provided in all study programs. They are equipped with materials that have to do with writing activities, for example understanding spelling, terms, using effective sentences, developing paragraphs to making scientific discourse in accordance with their respective study programs. As a lecturer, the existing paradigm of course must be changed, an Indonesian language lecturer, must be able to open a student's perspective to understand how important learning good and right Indonesian language particularly in scientific writing (Šubelj, Fiala, Ciglarič, \& Kronegger, 2019) with a standardized rule. The ability to write of Indonesian students is very alarming. They do not have the ability to write, have no creativity and are powerless to accept the concepts of writing (Lachner, Burkhart, \& Nückles, 2017). Students are just writing, so sometimes there is a feeling of insecurity. Blended 
learning is as a technology that combines all the elements of the media in the learning process (Boulton, Kent, \& Williams, 2018) starting from text, sound, still images, moving images, animation and video.(Nazarenko, 2015) In the today's digital era, it can be implemented in collaborative scientific writing. Based on these conditions there are some points; 1 . writing is a job that is considered difficult by students, 2 the type of learning method does not fit to the students' need so it does not foster their interest to write, and 3 in the lecture process, the lecturer gives more material related to the lecture unit, does not provide signs in scientific writing, without considering scientific writing practices. Thus, lecturers actually do not know whether students can write scientifically or not. The existing learning is more impressed as fulfilling obligations between lecturers and students. On the one hand, the lecturer gives the final assignment in the form of writing a scientific work. On the other hand, students write scientific paper(Ecarnot, Seronde, Chopard, Schiele, \& Meneveau, 2015) as final assignments to pass the course. In collaboration with collaborative learning, the advanced level of students in university have been able to become writers who master several criteria that have been obtained from the received material in class or read the results of research using collaborative learning. From the description of the situation and conditions above, it is very necessary to conduct action research in this regard to improve the situation and practice of teaching processes by utilizing information technology. In the context of learning to write scientific paper in higher education, the technology for learning becomes one of the devices that can support the success of the goals.

\section{Literature Review}

A study shows that students who lack confidence in learning English (Hong, Hwang, Tai, \& Chen, 2014) tend to imitate and internalize other people's writing(Özer, 2009). While those who are confident, and always collaborate with their friends online (Zhang, Meng, Ordóñez de Pablos, \& Sun, 2019), they are significantly able to develop affective domains in language. Syafi'ie stated that to be able to produce good writing, a writer must have several abilities such as: 1 . The ability to find problems to be written;(Sung, 2017) 2. Sensitivity to the condition of the reader;(Ulicheva, Harvey, Aronoff, \& Rastle, 2018) 3. Arrange writing planning(HenHerbst \& Rosenblum, 2019); 4, Ability to use language(Sheppard, Manalo, \& Henning, 2018) 5, Ability to start writin(Cuschieri, Grech, \& Savona-Ventura, 2019)g and 6, Ability to check writing themselves(Boulton et al., 2018).

\section{$3 \quad$ Methodology}

One strategy to improve the quality of education is to provide opportunities for lecturers to solve learning and non-learning problems professionally and collaboratively through controlled action research(Xiong \& Proctor, 2018). The most appropriate learning for this is collaborative learning. Collaborative learning provides the opportunity for students to be able to assess the results of their own writing together with 
classmates. Thus, students can see, repair and determine which of the scientific papers is the best. Students are encouraged to use references to support the tasks given to them in solving the problem. Because of group work, all assignments given must be distributed to all members in the group. This will help develop the ability to cooperate in research, and to get used to the use of the Internet effectively. Members in groups jointly learn to solve problems. The lecturer assesses the progress of each group, and gives advice to each group. In addition, the instructor must be prepared to provide consultations, and facilitate the process by requesting reports of progress made by the group. Social media can be maximized to solve this problem. The learning process is using collaborative learning with computer technology. The two online students are asked to chat, and write texts in English or other UN languages. Researchers want to reconstruct that collaborative learning can improve writing skills through four stages. Furthermore, scientific writing is an interesting, challenging activity and it requires adequate abilities since it requires critical, logical, coherent and systematic maturity of mind. The better our thinking, the better our work will be appreciated by others. It can be assumed that scientific writing encourages someone to become a better reader and more concerned with other writers' ideas. Collaborative learning will succeed if it is formed in small groups as a collective effort to achieve a common goal. Planning actions that have been carried out include: Action Scenarios, Preparation of Learning Facilities, Preparation of Research Instruments, Implementation of Actions and Observations.

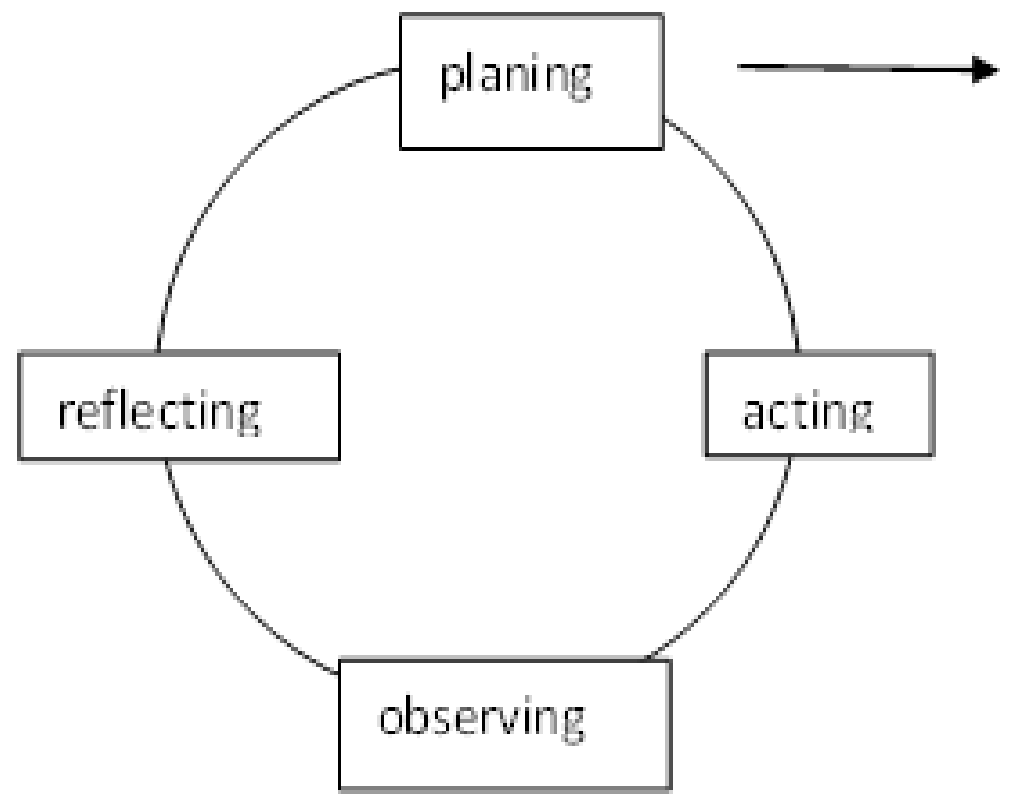

Fig. 1. Action Cycle Model 
The data collection techniques used are, organizing observation sheets, writing field notes of interviews, writing instrument, creating a rubric for Assessing the Ability of Writing Scientific Paper.

\section{$4 \quad$ Results and Findings}

At least there are some reasons why collaborative learning is the most effective to do:

- Members in their group will provide more information, perspectives and opinions

- They will think harder and creatively about what will be written

- They will be more confident among their members

- Some mistakes made in groups are more easily detected by other friends

This learning illustrates that in collaborative learning teams (study groups) are responsible for solving problems. Students must have enough information to solve problems. If not, they can search for and identify other sources, such as journals, books, videos, or the internet. In general, it can be said that collaborative learning can improve the ability to write together, because in their work and assignments they always do it in groups, so that the various problems faced can be immediately solved in groups as well. The first four stages of learning are collaborative learning conducted in groups, both small groups and large groups. Second, collaborative learning can improve the ability of the author by mastering six domains including: ganre, writing process, rhetoric, subject matter, community discourse and metacognitive knowledge. Third, collaborative learning can develop learners' knowledge through eight habits to think together which includes surviving, mastering learning, trying challenges, responding critically positively, engaging in collaboration, understanding how to write in complex contexts, and engaging in metacognition. Fourth, collaborative learning can improve the ability of writers from various aspects such as personal, professional and academic experience. The results of the action research that has been carried out show an increase in the results of the ability to write student scientific articles, as seen below:

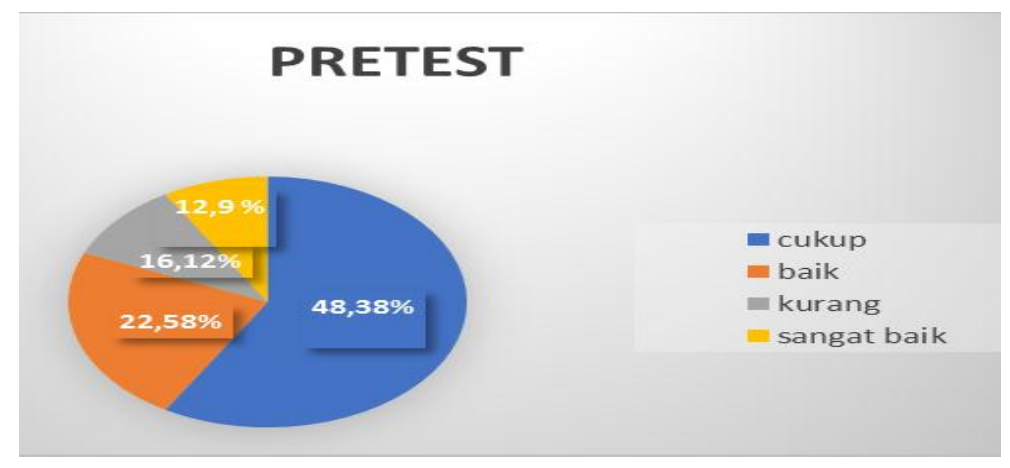

Fig. 2. Pre test and Pre Action 
From a number of students consisting of male and female students who took the pretest, the following data were obtained: only 4 students or $12.9 \%$ scored very well ( 80 and above), 7 students or $22.58 \%$ got good grades (69-79), 15 students or $48.38 \%$ received sufficient grades (55-68), and 5 students or $16.12 \%$ received less marks (4554).

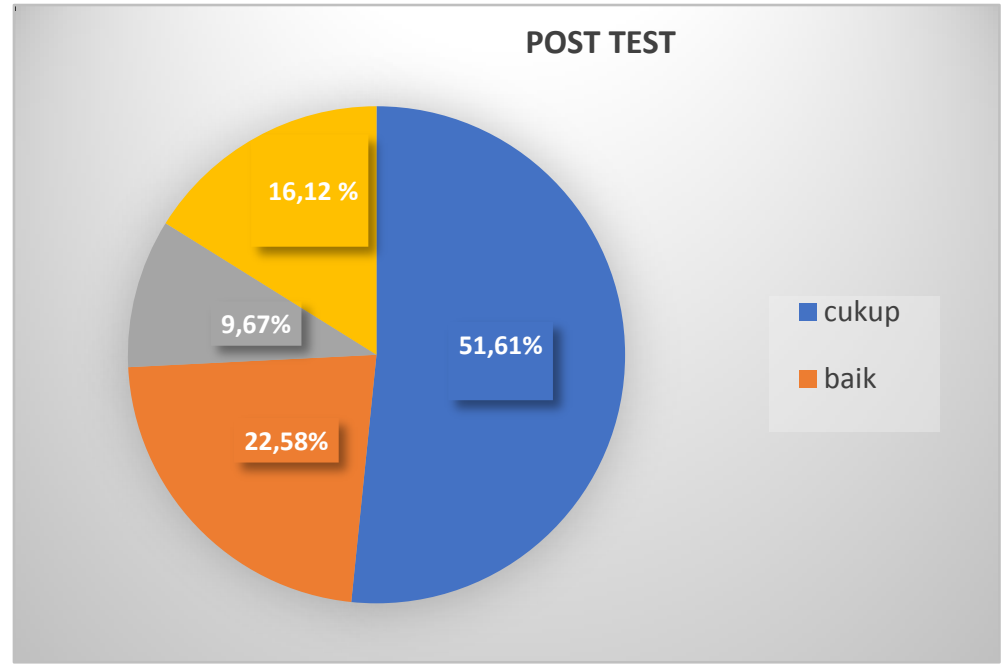

Fig. 3. Pre-action post test

While for the post test, the following data were obtained: There were 5 students or $16.12 \%$ got very good grades (80 and above)), 7 students or $22.58 \%$ got good grades (69-79), 16 students or $51.61 \%$ gets enough value (55-68), and 3 students or $9.67 \%$ get less marks (45-54).

Fifth, collaborative learning is more effective in providing writing lessons. Sixth, collaborative learning causes active participation of each participant in a group that is flexible, has a quality, and contributes to developing a positive attitude. Efforts to increase lecturer competition to solve learning problems will have a double positive impact. First, the ability to solve learning problems will increase. Second, solving learning problems through a controlled investigation will be able to improve the quality of content, input, process, infrastructure, and learning outcomes. Third, the increase in the two abilities will lead to an increase in the quality of graduates.

\section{Conclusion}

Writing skills are not as easy as we imagine. Various abilities are needed to produce a writing that meets the wishes of the reader. Therefore, before our writing is read by others, we need to check it to minimize errors. A good writer must be able to interact with the surrounding environment, in order to get interesting inspiration to discuss. The point is a good writer is a writer who had previously prepared him or 
herself physically and mentally. By birth, it means that many references have to be used as references when he writes

\section{Acknowledgement}

Sulfikar Sallu ID Scopus 57200989289 doctoral students of Education Technology, State University of Jakarta, and Lecturer at the Faculty of Information Technology, November 19, Kolaka.

\section{$7 \quad$ References}

[1] Boulton, C. A., Kent, C., \& Williams, H. T. P. (2018). Virtual learning environment engagement and learning outcomes at a 'bricks-and-mortar' university. Computers \& Education, 126, 129-142. https://doi.org/10.1016/j.compedu.2018.06.031

[2] Cuschieri, S., Grech, V., \& Savona-Ventura, C. (2019). WASP (Write a Scientific Paper): Structuring a scientific paper. Early Hum Dev, 128, 114-117. https://doi.org/10.1016/j.earlhumdev.2018.09.011

[3] Ecarnot, F., Seronde, M. F., Chopard, R., Schiele, F., \& Meneveau, N. (2015). Writing a scientific article: A step-by-step guide for beginners. European Geriatric Medicine, 6(6), 573-579. https://doi.org/10.1016/j.eurger.2015.08.005

[4] Hen-Herbst, L., \& Rosenblum, S. (2019). Which characteristics predict writing capabilities among adolescents with dysgraphia? Pattern Recognition Letters, 121, 6-12. https://doi. org/10.1016/j.patrec.2018.04.021

[5] Hong, J.-C., Hwang, M.-Y., Tai, K.-H., \& Chen, Y.-L. (2014). Using calibration to enhance students' self-confidence in English vocabulary learning relevant to their judgment of over-confidence and predicted by smartphone self-efficacy and English learning anxiety. Computers \& Education, 72, 313-322. https://doi.org/10.1016/j.compedu.2013.11.011

[6] Lachner, A., Burkhart, C., \& Nückles, M. (2017). Formative computer-based feedback in the university classroom: Specific concept maps scaffold students' writing. Computers in Human Behavior, 72, 459-469. https://doi.org/10.1016/j.chb.2017.03.008

[7] Nazarenko, A. L. (2015). Blended Learning vs Traditional Learning: What Works? (A Case Study Research). Procedia - Social and Behavioral Sciences, 200, 77-82. https://doi. org/10.1016/j.sbspro.2015.08.018

[8] Özer, N. Ö. (2009). Consciousness of writing, spelling errors and their causes in Turkish alphabet. Procedia - Social and Behavioral Sciences, 1(1), 1353-1356. https://doi.org/10. 1016/j.sbspro.2009.01.239

[9] Sheppard, C., Manalo, E., \& Henning, M. (2018). Is ability grouping beneficial or detrimental to Japanese ESP students' English language proficiency development? English for Specific Purposes, 49, 39-48. https://doi.org/10.1016/j.esp.2017.10.002

[10] Šubelj, L., Fiala, D., Ciglarič, T., \& Kronegger, L. (2019). Convexity in scientific collaboration networks. Journal of Informetrics, 13(1), 10-31. https://doi.org/10.1016/j.joi.2018. $\underline{11.005}$

[11] Sung, E. (2017). The influence of visualization tendency on problem-solving ability and learning achievement of primary school students in South Korea. Thinking Skills and Creativity, 26, 168-175. https://doi.org/10.1016/j.tsc.2017.10.007 
[12] Ulicheva, A., Harvey, H., Aronoff, M., \& Rastle, K. (2018). Skilled readers' sensitivity to meaningful regularities in English writing. Cognition. https://doi.org/10.1016/j.cognition. $\underline{2018.09 .013}$

[13] Xiong, A., \& Proctor, R. W. (2018). The role of task space in action control: Evidence from research on instructions. 69, 325-364. https://doi.org/10.1016/bs.plm.2018.09.007

[14] Zhang, X., Meng, Y., Ordóñez de Pablos, P., \& Sun, Y. (2019). Learning analytics in collaborative learning supported by Slack: From the perspective of engagement. Computers in Human Behavior, 92, 625-633. https://doi.org/10.1016/j.chb.2017.08.012

[15] Zillmer, N., \& Kuhn, D. (2018). Do similar-ability peers regulate one another in a collaborative discourse activity? Cognitive Development, 45, 68-76. https://doi.org/10.1016/j.cog dev.2017.12.002

\section{Authors}

Dede Hasanuddin and Emzir, Sabarti Akhadiah work at State University of Jakarta, Jakarta, Indonesia.

Article submitted 2019-06-29. Resubmitted 2019-08-02. Final acceptance 2019-08-02. Final version published as submitted by the authors. 


\section{$9 \quad$ Appendices}

Table 1. Instrument

\begin{tabular}{|l|l|}
\hline $\begin{array}{l}\text { Aspects of ability to write } \\
\text { scientific articles }\end{array}$ & \multicolumn{1}{c|}{ Description } \\
\hline Logical thinking & Sequence in scientific thinking so that it is easily understood by others \\
\hline Data objectivity & The data are written in accordance with the data found in the field \\
\hline Systematic & Regularity in writing scientific articles that are commonly used \\
\hline 1. Title of the Artikel & $\begin{array}{l}\text { The ability to produce the right article title in accordance with the discussed } \\
\text { topic }\end{array}$ \\
\hline $\begin{array}{l}\text { 2. Name and Adress of the } \\
\text { article researcher }\end{array}$ & $\begin{array}{l}\text { Inclusion of the name and address which usually contains the name of the } \\
\text { questionnaire and the email of the researcher }\end{array}$ \\
\hline 3. Abstract and keywords & The ability to make the essence of scientific writings in whole \\
\hline 4. Introduction & $\begin{array}{l}\text { The ability to deliver the reader, why he or she writes an is interested with the } \\
\text { title, usually contains background, preliminary data found in the field, faced } \\
\text { constraints and offered solutions. }\end{array}$ \\
\hline 5. Literature Review & $\begin{array}{l}\text { The ability to take the right reference source, accurately in accordance with } \\
\text { the topic of discussion. }\end{array}$ \\
\hline 6. Methodology & The research procedure is explained transparently \\
\hline 7. Result and Discussion & Ability to explain systematically, measurably and clearly \\
\hline $\begin{array}{l}\text { 8. Conclusion, Suggestion } \\
\text { and significance or implica- } \\
\text { tion }\end{array}$ & $\begin{array}{l}\text { The ability to make conclusions from what has been described, make } \\
\text { suggestions to others, and apply research results }\end{array}$ \\
\hline 9. References & Ability to research the suitable reference source in accordance with the rules \\
\hline Vocabulary Mastery & $\begin{array}{l}\text { The ability to use scientific words, cohesive of word choices, and denotative } \\
\text { meaning }\end{array}$ \\
\hline $\begin{array}{l}\text { Ability to develop } \\
\text { paragraphs }\end{array}$ & The ability to use scientific words, word choices, and denotative meaning \\
\hline Use of Enhanced Spelling & The ability to use proper spelling such as capital letters and punctuation. \\
\hline $\begin{array}{l}\text { The use of effective sen- } \\
\text { tences }\end{array}$ & The ability to use effective sentences \\
\hline
\end{tabular}

Table 2. Scientific Writing Ability Assessment Rubric

\begin{tabular}{|l|l|c|}
\hline \multicolumn{1}{|c|}{ Indicators } & \multicolumn{1}{|c|}{ Assessment Aspect } & $\begin{array}{c}\text { Score of } \\
\text { Aspect }\end{array}$ \\
\hline Logical thinking & Not coherent in thinking and difficult for readers to understand & 1 \\
\hline & Less coherent in thinking and somewhat difficult for readers to understand & 2 \\
\hline & Coherent in thinking and easily understood by the reader & 3 \\
\hline & Very coherent in thinking and easily understood by the reader. & 4 \\
\hline & Do not write the data & 1 \\
\hline & Written data is different with the data found in the field & 2 \\
\hline & The data written is not in accordance with the data found in field & 3 \\
\hline Data objectivity & The written data is in accordance with the data found in the field. & 4 \\
\hline tery & Use non sientific words kata-kata, inappropriate dictioni, do not have deno- & 1 \\
\hline & tative meaning & 2 \\
\hline & Using scientific words, inapproprite diction, and not denotative & 3 \\
\hline & Using scientific words, correct diction, and not denotative & 4 \\
\hline & Using scientific words, correct diction, and denotative meaning & \\
\hline
\end{tabular}




\begin{tabular}{|c|c|c|}
\hline The use of EYD & $\begin{array}{l}\text { Do not use the right spelling in the use of capital letters, the use of letters } \\
\text { and punctuation. }\end{array}$ & 1 \\
\hline & $\begin{array}{l}\text { Using the right spelling in the use of capital letters, even though there are } \\
\text { letters and the use of incorrect punctuation. }\end{array}$ & 2 \\
\hline & $\begin{array}{l}\text { Using the right spelling in the use of capital letters, the use of letters even } \\
\text { though there are incorrect punctuation. }\end{array}$ & 3 \\
\hline & $\begin{array}{l}\text { Using the right spelling in the use of capital letters, letter usage and the use } \\
\text { of punctuation. }\end{array}$ & 4 \\
\hline \multirow[t]{4}{*}{$\begin{array}{l}\text { Using Effective } \\
\text { sentences }\end{array}$} & Using effective sentences & 1 \\
\hline & Using non effective sentences & 2 \\
\hline & Less effective sentences & 3 \\
\hline & Using Effective sentences & 4 \\
\hline \multirow[t]{5}{*}{$\begin{array}{l}\text { Developing para- } \\
\text { graph }\end{array}$} & Develop non-deductive, inductive, and not inductive-inductive paragraphs & 1 \\
\hline & $\begin{array}{l}\text { Developing paragraphs is only deductive, inductive, and not inductive- } \\
\text { inductive }\end{array}$ & 2 \\
\hline & Develop deductive, inductive and inductive-inductive paragraphs & 3 \\
\hline & Develop deductive, inductive, and deductive-inductive paragraphs & 4 \\
\hline & SYSTEMATIC WRITING OF SCIENTIFIC PAPER & \\
\hline Title of the article & The title is incorrect and does not match the topic discussed. & \\
\hline \multirow{7}{*}{\begin{tabular}{|l|} 
2. Name of \\
researcher, \\
institution and \\
email of researcher
\end{tabular}} & Titles are less precise and in accordance with the topics discussed. & \\
\hline & The title is right and in accordance with the topic discussed. & \\
\hline & The title is very precise and in accordance with the topics discussed. & \\
\hline & $\begin{array}{l}\text { Does not include names, does not include institutions and does not include } \\
\text { researcher emails }\end{array}$ & \\
\hline & $\begin{array}{l}\text { Include names, do not include institutions and do not include researcher } \\
\text { emails }\end{array}$ & \\
\hline & Include names, institutions, and do not include researcher emails & \\
\hline & Include the name, institution, and email of the researcher & \\
\hline \multirow{4}{*}{$\begin{array}{l}\text { 3. Abstract and } \\
\text { Keywords }\end{array}$} & Digest / overview is unclear, not interested and does not use keywords. & \\
\hline & Incomplete overview, does not accept and does not use keywords. & \\
\hline & Unclear summary, interesting and does not use keywords. & \\
\hline & IClear overview, very detail and use keywords & \\
\hline \multirow{4}{*}{ 4.Introduction } & $\begin{array}{l}\text { Not detail in describing, do not write down the reason why the writer is } \\
\text { interested in the title, no preliminary data is attached, do not convey } \\
\text { constraints that occur in the field and no solutions are offered. }\end{array}$ & \\
\hline & $\begin{array}{l}\text { Menguraikan secara terperinci dengan menuliskan mengapa tertarik dengan } \\
\text { judul, ada data awal yang dilampirkan, tidak menyampaikan kendala- } \\
\text { kendala yang terjadi di lapangan dan tidak ada solusi yang ditawarkan. }\end{array}$ & \\
\hline & $\begin{array}{l}\text { Describe in detail by writing down why you are interested in the title, there } \\
\text { are preliminary data attached, conveying the obstacles that occur in the field } \\
\text { and no solutions offered }\end{array}$ & \\
\hline & $\begin{array}{l}\text { Describe in detail by writing down why you are interested in the title, there } \\
\text { are preliminary data attached, conveying the obstacles that occur in the field } \\
\text { and there are solutions offered. }\end{array}$ & \\
\hline $\begin{array}{l}\text { 5. Literature } \\
\text { review }\end{array}$ & $\begin{array}{l}\text { Using a theory study that is not relevant to the topic raised, not renewable, } \\
\text { and does not quote from the original source book. }\end{array}$ & \\
\hline
\end{tabular}




\begin{tabular}{|c|c|}
\hline & $\begin{array}{l}\text { Using a theory study that is relevant to the topic raised, not renewable, and } \\
\text { does not quote from the original source book. }\end{array}$ \\
\hline & $\begin{array}{l}\text { Using a theoretical study that is relevant to the topic raised, renewable, and } \\
\text { does not quote from the original source book. }\end{array}$ \\
\hline & $\begin{array}{l}\text { Using theoretical studies that are relevant to topics raised, renewable, and } \\
\text { quoted from the original source book. }\end{array}$ \\
\hline & Writing down the methodology is not systematic, unclear and not detailed \\
\hline 6 Metodologi & Writing out the methodology systematically, unclear and not detailed \\
\hline 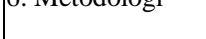 & Write down the methodology systematically, clearly and not in detail \\
\hline & Write down the methodology in a systematic, clear and detailed manner \\
\hline $\begin{array}{l}\text { 7.Discussion and } \\
\text { Research result } \\
\end{array}$ & Discussing in a systematic, immeasurable and unclear manner \\
\hline $\begin{array}{l}\text { 8.Conclusion, } \\
\text { Suggestion and } \\
\text { Implication }\end{array}$ & Discuss systematically, measurably and unclear \\
\hline 9.References & \\
\hline & Discuss systematically, measurably and unclear \\
\hline & Discuss systematically, measurably and clearly \\
\hline & $\begin{array}{l}\text { Does not make conclusions from what has been described, does not make } \\
\text { suggestions to others, and does not apply the results of research }\end{array}$ \\
\hline 6 Methodolooy & $\begin{array}{l}\text { Make conclusions from what has been described, do not make suggestions to } \\
\text { others, and do not apply the results of research }\end{array}$ \\
\hline o. Ivietnodorogy & $\begin{array}{l}\text { Make conclusions from what has been described, make suggestions to } \\
\text { others, and do not apply the results of research }\end{array}$ \\
\hline & $\begin{array}{l}\text { Make conclusions from what has been described, make suggestions to } \\
\text { others, and apply the results of research }\end{array}$ \\
\hline & $\begin{array}{l}\text { Writing down reference sources is not alphabetical, does not follow the } \\
\text { correct research rules, originating from one source (book) }\end{array}$ \\
\hline & $\begin{array}{l}\text { Writing down reference sources alphabetically, following the correct } \\
\text { research rules, comes from one source (book) }\end{array}$ \\
\hline $\begin{array}{l}\text { I.Discussion and } \\
\text { Research result }\end{array}$ & $\begin{array}{l}\text { Writing down reference sources alphabetically, following the correct } \\
\text { research rules, comes from two sources (books, and scientific journals) }\end{array}$ \\
\hline & $\begin{array}{l}\text { Writing down reference sources alphabetically, following the correct } \\
\text { research rules, comes from various sources (books, scientific journals, and e- } \\
\text { books) }\end{array}$ \\
\hline
\end{tabular}

